UNTAG Law Review (ULREV)

Volume 3, Issue 1, May 2019, PP 1-10

ISSN 2549-4910 (online) \& ISSN 2579-5279 (print)

http://jurnal.untagsmg.ac.id/indeks.php/ulrev/indeks

www.fakhukum.untagsmg.ac.id

\title{
CHALLENGES OF THE INDONESIAN REPUBLIC GENERAL ELECTION COMMISSION (KPU RI) TO INCREASE VOTER PARTICIPATION
}

Andina Elok Puri Maharani, Rizma Dwi Nidia

Lecturer of Faculty of law at Sebelas Maret Universit;

Student of Faculty of law at Sebelas Maret University

Email : andina_hukum@yahoo.com;rizmadwinidia@gmail.com

\begin{abstract}
This research examines problems that arise and become obstacles in the process of organizing general elections and the challenges of the General Election Commission (KPU) in increasing voter participation in general elections.

The purpose of this study is to find out what obstacles arise in the implementation of the General Election related to the role of the KPU to increase public participation in general elections. This type of research is empirical research and the data used are primary data by conducting interviews with KPU commissioners accompanied by an analysis of secondary data in the form of legislation.

The results of this study indicate that barriers that can interfere with the process of holding elections, arise from news hoaxes and some obstacles that are classified based on the group of voters. Every segment of society has different needs, so the method used to increase community participation is tailored to the needs of the community in each segment.
\end{abstract}

Keywords: Election Commission, Community Participation, Legislative Election

\section{INTRODUCTION}

This study examines the obstacles that arise in the implementation of Law Number 7 of 2017 concerning Elections related to the role of the KPU in efforts to increase public participation in the Legislative General Election. General Election (Election) is a means of implementing people's sovereignty which is carried out directly, publicly, freely, confidentially, honestly \& fairly in the Unitary State of the Republic of Indonesia based on the 1945 Pancasila \& State Constitution of the Republic of Indonesia. Elections are carried out effectively and efficiently based on direct, general, free, confidential, honest and fair principles. ${ }^{1}$ General Election

1 Nurkinan, "Peran Partisipasi Masyarakat Dalam Pengawasan Pemilihan Umum Serentak Anggota Legislatif dan Pilpres Tahun 2019”. Jurnal Politikom Indonesiana, Vol. 3 No. 1 Juli 2018. P.26 
(Election) is one of the pillars of democracy as a means of realizing people's sovereignty to produce a democratic government. The government produced from the General Election also becomes a benchmark for the implementation of democracy in a country, where the people are directly involved in determining the direction and political policies of the country for one future government period. ${ }^{2}$

Related to its relationship with democracy, political participation influences the legitimacy of the community towards the course of a government. In an election, for example, political participation influences the legitimacy of the community to the chosen candidate pair. Every community has standards or tastes to determine their choices in elections. It can be said that the future of elected public officials in an election depends on the tastes of the people as voters. Not only that, the political participation of the public in elections has a very large role and can be seen as the control of the community towards a government. The control given varies depending on the level of political participation of each. Aside from being the core of democracy, political participation is also closely related to fulfilling the political rights of citizens. ${ }^{3}$

Participation aims to encourage active democratic activities for all electoral processes. The participation of the community is an indicator of improving the quality of democracy and the nation's political life. Political participation of the community, is always needed in every election to participate in supervising or monitoring the running of the elections. ${ }^{4}$

At each Election Implementation, of course, there are no problems that can hinder the election process. Problems that are always a task to be resolved by Election Organizers. For the sake of the success of the election, the challenge of avoiding problems that can disrupt the process of holding elections and finding solutions to these problems has become an interesting thing to study. Especially in the discussion of this research is the Issue of Community Political Participation as Voters. This has always been the concern of the Election Organizers, because the level of community participation in contributing to the electoral process can be a measure of the success of a State to build a community mindset regarding the importance of community participation in the progress of the State.

\section{Research Methods}

This research uses qualitative methods, namely research that produces written or verbal words from people who can be observed. The data that has been obtained will be analyzed qualitatively and described in descriptive form with more description of the results of the

2 Arry Dharmawan, “Inovasi Model Sosialisasi Peran Serta Masyarakat Dalam Pemilu”. Jurnal Wacana Politik Vol. 1 No. 2 Oktober 2016.p. 1

3 Ibid.

4 Nurkinan,Op.Cit.p. 28 
literature study. The type of data used in this study are primary data and secondary data. Primary data is obtained directly from the community and library materials. Secondary Data is data obtained from library materials in the form of information that is directly obtained through library studies, related laws and regulations and secondary legal materials derived from the type of literature both from books, research results, results of studies, and articles in journals for look for various theories related to the substance of research. Data analysis techniques are carried out through data reduction, data presentation and data verification.

\section{Hoax News}

In each General Election (Election), KPU has an important role to Increase Community Participation. Of course, efforts to increase community participation are not immune from obstacles that can disrupt the administration of elections. From the author's research, the obstacles experienced by KPU in general, one of which is related to the circulation of hoax news or untrue news. The development of the current social media communication system is indeed very helpful in the activities carried out by the KPU regarding the dissemination of information on elections. However, the spread of hoax news is an obstacle that affects public confidence in the performance of the KPU. This hoax news distribution is certainly very fast considering one of the advantages of social media, which is spreading the news quickly. So the KPU must also quickly provide clarification that the news is not true.

One example of hoax news that has been circulating is like in January 2019 and there were 7 (seven) ballot containers that had been pierced at Tanjung Priok Port. News of the hoax circulating said that there were 70 (seventy) million ballots that had been punched in serial number 01 in seven containers. On the tape also said the ballot came from China and had been seized by the Navy. ${ }^{5}$

Voters in elections are people who will determine the leaders of this nation. This momentum is a momentum that cannot be repeated, so that it requires the Indonesian people to be smart voters in determining the Indonesian leader. Being a smart voter according to the KPU is those who check their own names on the Permanent Voters List (DPT) both online and in the nearest Sub-district office. If there is no name, it can be filed 2 weeks before the election. It must hold the objective principle to see the track record of the people's representatives or vice presidential candidates properly. Not easily provoked by hoaxes and incitement in cyberspace or social media Using their respective voting rights according to the provisions. ${ }^{6}$

5 (https://news.detik.com/berita/d-4368872/kpu-penyebar-berita-bohong-surat-suara-tercoblos-harusditangkap diakses Maret 2019)

6 (https://www.mafindo.or.id/2018/12/14/menjadi-pemilih-cerdas-antihoax-di-dunia-digital/ diakses Maret 2019) 
KPU as the Election Organizing Commission does not have the authority to act on forms of irregularities. The authorities are Bawaslu and voters can report acts of irregularities in elections. And make sure the campaign of political parties or candidates must be in a place that is legally legal. Like not in educational facilities or places of worship. Even intelligent voters cannot be trapped in hoaxes. Voters can download Hoax Buster Tools (HBT) on Android phones. Being polite and smart voters and not trapped in hate speech and hoax are the goals of a successful election. Anti-discrimination and hoax campaigns will make civilized elections for the Millennials. ${ }^{7}$

\section{Voter Group Classification}

In addition to Hoax news that weakens the KPU in the eyes of the public, there are several implementation problems / obstacles that arise from several voter groups, namely:

\section{Beginner Voters Group}

Voters who are in the political category are the first time to use their voting rights. This beginner voter political orientation is always dynamic and will change according to existing conditions and the factors that influence it. It can be said that here beginner voters are still in the learning stage to use their political suffrage for the first time. ${ }^{8}$

The presumption of beginner voters that the campaign is an activity that takes time and collides with their daily activities resulting in Beginner Voters are reluctant to participate in campaign activities. There are also beginner voters who think that they are not participating in the campaign because they do not like the hustle and bustle of the open campaign atmosphere. Because sometimes, seeing from the implementation of previous election campaigns, it can still be seen that actually activities that are not needed or have nothing to do with the campaign, such as convoys on the highway using motorized vehicles whose booming voice, is carried out in a row and traveling to several regions, it is still carried out by several groups. So that these activities that the author considers tend to be chaotic, and cause discomfort for some people. Factors that hinder beginner voters' political participation, namely the busy daily activities of the average voter are students, students and workers. It is very reasonable for beginner voters whose average age ranges from 17-21 years. This is what makes beginner voters reluctant to carry out political activities which are generally considered to be time consuming.'

\section{Women's Voter Group}

Women voters in the political sector still have a lot of discrimination against women, even

7 https://www.mafindo.or.id/2018/12/14/menjadi-pemilih-cerdas-antihoax-di-dunia-digital/ diakses Maret 2019).

8 Primandha Sukma Nur Wardhani, "Partisipasi Politik Pemilih Pemula dalam Pemilihan Umum”. Jurnal Pendidikan Ilmu-Ilmu Sosial Vol.10 No. 1 Tahun 2018. Hlm 59

9 Ibid.p. 60-61 
though women are the majority of the population in Indonesia who are also voters in general elections. However, it can be seen from every political institution, women are always minority or marginal and representation is low.$^{10}$

Freedom to choose a legislature and president is a private right of the community and of course women. But in reality, women often experience intervention when in the process of seeking political information to determine their political choices. So, the right to his freedom chooses to be disturbed because of the encouragement or influences from other parties. The independence of women in deciding political choices turned out to have greater challenges than within their own family members. Husbands, parents and siblings have a big role to play in destroying women's freedom in determining their political choices. The husband is the most dominant person in intervening with his wife in family members. Most women turned out to follow the political choices suggested by their husbands. There are also women who remain independent in making political choices. ${ }^{11}$

\section{Disability Group}

Disability groups do not escape the problems of holding elections. Always a concern for election participants regarding disability issues, it is expected that the attention of prospective leaders, so that disability issues can be politically advocated by selected leaders. The form of political participation expected by persons with disabilities is to communicate or have direct contact with the government. With these activities, it is expected that the government knows exactly what is needed by persons with disabilities directly from persons with disabilities themselves. However, once again their awareness to participate in political activities is inversely proportional to their political participation. The data in Rachmad Gustomi's research actually shows that awareness of the importance of expressing opinions directly to the government is not consistent with its practice. Only a portion of persons with disabilities have expressed their opinions directly to the government. ${ }^{12}$

One indicator of political participation in elections is the granting of voting rights. KPU as the election organizer whose duty is to carry out the election has the obligation to fulfill all the needs of its citizens by providing facilities and infrastructure that are in accordance with the needs of the community, so that they can exercise their right to vote independently and easily, and enforce election principles . Disability is no exception to people who physically have a disorder with society in general. The need for persons with disabilities to exercise their right to vote in the conduct of elections must be fulfilled in order to be able to act independently. The

10 Juwito. Syfa Syarifa Alawiah, "Pola Komunikasi Politik Perempuan Dalam Pemilu”. Jurnal Ilmu Komunikasi Vol 1.No. 2 Oktober 2009.p. 121-127

11 Ibid.p. 127

12 Rachmat Gustomy, "Partisipasi Politik Difabel Di 2 Kota”. Indonesian Journal of Disability Studies (IJDS). Vol. 4 No. 1 Tahun 2017.p. 157 
polling stations provided are places that are disability-friendly. So, in terms of creating a polling place that is friendly to disability, there is a need for simulase directly, carried out by election organizers, using wheelchairs for example, so that election organizers also understand and feel directly, what is actually needed by disability groups when use their right to vote at the polling station.

\section{Another Factor}

\section{Low Voter Participation}

Based on the formulation of the Economist Intelligence Unit (EIU), an established democracy, voter participation is consistent with the figure of 70 percent. Regions and community groups with low voter participation are the target of voter education because low participation can harm democracy. Low participation also makes election implementation activities ineffective and inefficient. ${ }^{13}$

The low level of political participation generally arises from apathy and a priori attitude towards political activities and activities, where people prefer to carry out their daily activities such as working, exercising, social clubs, sightseeing and so on, which they feel can provide a more tangible benefit than having to participate in politics. Another factor that is also closely related to political participation is the level of education of the community, where the higher the level of education of the community, usually will be directly proportional to their tendency to participate in politics. This is the irony in many developing countries, where there are still not many people who are aware of their political needs and obligations, thus impacting on the level of community participation in the generally low political agenda. ${ }^{14}$

\section{High Potential Election Violations}

The potential for high electoral violations occurs in areas where in the history of elections there have been repeated election violations, or violations that are massive, or structured, or systematic. In essence, the area in the implementation of the election occurred various events that violated statutory provisions. This potential can be triggered by various things such as low knowledge of organizers, participants and voters about electoral affairs, lack of supervision because the area is difficult to access, and political kinship because the community is homogeneous. There are three categories of election violations, namely violations of the ethics of election administrators, violations of electoral administration and election crimes. Election violations can be sourced from election organizers, election participants, the government and

13 Ibid.

14 Maslekah Pratama Putri. "Peran Komisi Pemilihan Umum Dalam Sosialisasi Pemilu sebagai upaya Untuk Meningkatkan Partisipasi Politik Masyarakat Pada Pemilu Presiden 2014 di Kalimantan Timur”. eJournal Ilmu Komunikasi, Vol. 4, No. 1, 2016.p. 31 
Society. ${ }^{15}$

Several election violations that have occurred based on Heru Cahyono's research: ${ }^{16}$

a. Chaotic Voter Registration and Data Collection of Sustainable Population(P4B)

Based on Heru Cahyono's research, the method and schedule of population data can influence the distribution of population data. When statisticians in the field did not know exactly the demographic map of the local community, they were not accompanied by officials. The data collection process is carried out by statistical officers, that if it is carried out during the day, many people will not be at home especially those who work outside the home. So, allowing the presence of citizens who have not been registered, can create a gap for those who intend to use the situation to benefit certain parties.

\section{B. Voting Data Manipulation and Chaotic Information Technology Systems}

Seeing from the implementation of previous elections, a number of violations meant taking place during the vote count. Found many polling stations whose actual results do not match what is listed in the document at the level above. In this case, the deviation is carried out by the voting officer or the voting committee. This means that there are still many individuals who exploit the weaknesses at the polling station, and the lack of strict selection of Election Supervisory members and the lack of strict supervision of the holding of elections at polling stations, especially at polling stations located in remote areas, so that the network of independent monitors and Pawaslu. In the calculation of votes can also be used by individual election officers who can do data manipulation. Data previously clearly displayed at the polling station and the calculation has been witnessed clearly, but when the data is moved in the form of documents, the numbers change immediately.

\section{c. Neutrality of Civil Bureaucracy}

Except for the issue of vote counting, another vulnerable thing is the involvement of village heads or sub-district heads who become one of the party's success teams. The continued support of several village heads / village heads or sub-district heads to certain parties is something that is difficult to prove. Even though a figure like the village head has a strong influence on the citizens of his community, so if in the election he is still leaning on certain political forces, it will most likely be followed by his people.

\section{d. Money politic}

Take advantage of the weak economic conditions of the community to implement money

15 KPU RI, “Pedoman Pendidikan Pemilih”. Jakarta: KPU Republik Indonesia, 2015. p. 6-8

16 Heru Cahyono, "Pelanggaran Pemilu Legislatif 2004". Jurnal Penelitian Politik, Vol.1 No. 1 Tahun 2004. p. 12-22 
politics. The persistence of the practice of money politics is mainly influenced by the condition of the people who are under stressed socio-political and socio-economic conditions, so that the people will easily fade the idealism by just 2-3 liters of rice or 20,000-50,000 notes (twenty to fifty thousand).

e. Mental Project and the Scent of Money Politics at the KPU

Looking at the history of the cases found in the 2004 Election, the KPU as the election organizer was deemed not to meet expectations. The implementation of the 2004 Election was also marked by chaos in the procurement and distribution of logistics, as well as the weakness of the KPU's information technology system. Of course this is expected to not happen again in the next election.

\section{f. Intimidation}

Intimidation to influence voters does not only occur in conflict areas, but even in relatively safe areas there are still practices. ${ }^{17}$ Areas prone to conflict and violence are regions that have a high potential for clashes and / or physical clashes between two or more groups of people that can disrupt the administration of elections. Conflict can be triggered by a variety of factors ranging from social, political, cultural and economic. Areas prone to conflict and violence are the targets of voter education for a number of reasons. First, conflict can hamper people's access to vote. Second, conflict can cause anxiety and fear in the midst of society, which disrupts their independence in using their voting rights and disturbing. Third, conflict can disrupt, even frustrate the implementation of elections so that the circulation of power regularly in the area is hampered. ${ }^{18}$

Conflicts often arise in people's lives that have balanced strength. If a society that is sociologically inhabited by people who are of different religions and ethnicities or ethnicities, then that difference has the potential to trigger conflict and violence. Sometimes the conflicting parties often highlight personal and group interests; more concerned with selfinterest without seeing or caring for the interests of others, often bringing disharmony socially, economically, and politically. The lack of tolerance to other parties is still felt weak. ${ }^{19}$

In addition to the above factors, the results of David M. Liando's research mentioned that one of the factors that caused the community not to participate was the weak socialization of the ad hoc committee to the community regarding the provision of voting by the community. Some people still consider that the provision for voters is waiting for a written invitation from the committee. The results of the study state that one of the community factors that did not vote in

17 Ibid.

18 KPU RI, “Pedoman Pendidikan Pemilih”. Jakarta: KPU Republik Indonesia, 2015. p. 6-8

19 Ahmad Amiruddin, “Pilkada Serentak Dan Potensi Konflik di Sulawesi-Selatan”. 2017. p. 3 
the 2014 election was due to mistrust of legislative candidates, whether they were distrustful of campaign promises, uninterrupted with the vision and mission offered until there was public discomfort whether when they voted they would have an influence or change for the community. ${ }^{20}$

\section{Conclusion}

Barriers that can disrupt the election process arise from several groups of voters, as well as hoax news / incorrect news circulating regarding the holding of elections by the General Election Commission, incorrect news circulating quickly through the internet can affect public confidence in the KPU's performance as Election organizers. Every segment of society has different needs, so the method used to increase community participation is tailored to the needs of the community in each segment.

\section{Recommendation}

1. KPU collaborates in conducting socialization with each component of the community to increase voter participation

2. The KPU strengthens the information system network so that it is easily accessible to the public.

\section{Literature}

\section{Book:}

KPU RI. 2015. Pedoman Pendidikan Pemilih. KPU Republik Indonesia: Jakarta Journals, Papers and other publications :

Ahmad Amiruddin. Pilkada Serentak Dan Potensi Konflik di Sulawesi-Selatan. Tahun 2017.

Arry Dharmawan. Inovasi Model Sosialisasi Peran Serta Masyarakat Dalam Pemilu. Jurnal Wacana Politik Vol. 1, No. 2 Oktober 2016.

Daud M. Liando. Pemilu Dan Partisipasi Politik Masyarakat. Jurnal LPPM Bidang EkoSosBudKum Volume 3 Nomor 2 Tahun 2016 Edisi Oktober

Heru Cahyono. Pelanggaran Pemilu Legislatif 2004. Jurnal Penelitian Politik, Vol.l No. 1, Tahun 2004

Juwito. Syfa Syarifa Alawiah. Pola Komunikasi Politik Perempuan Dalam Pemilu. Jurnal Ilmu Komunikasi Vol 1. No.2 Oktober 2009

20 Daud M. Liando. “Pemilu Dan Partisipasi Politik Masyarakat”. Jurnal LPPM Bidang EkoSosBudKum Volume 3 Nomor 2 Oktober, 2016.p. 24-25 
Andina Elok Puri Maharani, Rizma Dwi Nidia : Challenges Of The Indonesian Republic ....

Maslekah Pratama Putri. Peran Komisi Pemilihan Umum Dalam Sosialisasi Pemilu sebagai upaya Untuk Meningkatkan Partisipasi Politik Masyarakat Pada Pemilu Presiden 2014 di Kalimantan Timur. eJournal Ilmu Komunikasi, Volume 4, Nomor 1, Tahun 2016.

Nurkinan. Peran Partisipasi Masyarakat Dalam Pengawasan Pemilihan Umum Serentak Anggota Legislatif Dan Pilres Tahun 2019. Jurnal Politikom Indonesiana, Vol.3 No.1 Juli 2018.

Primandha Sukma Nur Wardhani. Partisipasi Politik Pemilih Pemula dalam Pemilihan Umum. Jurnal Pendidikan Ilmu-Ilmu Sosial 10 (1) Tahun 2018

Rachmat Gustomy. Partisipasi Politik Difabel Di 2 Kota. Indonesian Journal of Disability Studies (IJDS). Vol. 4(1) Tahun 2017

\section{Internet:}

https://news.detik.com/berita/d-2639343/pilpres-2014-partisipasi-pemilih-di-solo-tertinggisejak-reformasi diakses Maret 2019.

https://www.mafindo.or.id/2018/12/14/menjadi-pemilih-cerdas-antihoax-di-dunia-digital/ diakses Maret 2019 